\title{
Widespread influence of resuspended sediments on oceanic particulate organic carbon: Insights from radiocarbon and aluminum contents in sinking particles
}

\author{
Jeomshik Hwang, ${ }^{1,2}$ Ellen R. M. Druffel, ${ }^{3}$ and Timothy I. Eglinton ${ }^{1}$ \\ Received 14 February 2010; revised 23 June 2010; accepted 14 July 2010; published 20 November 2010.
}

[1] Particulate organic carbon (POC) in the ocean often exhibits more depleted radiocarbon contents (lower $\Delta^{14} \mathrm{C}$ values) than expected if its sole source were POC recently synthesized by primary production and export from the overlying surface waters. An examination of available $\Delta^{14} \mathrm{C}$ data sets for sinking POC show that this phenomenon is both common and globally widespread. Also, a strong correlation is found to exist between $\Delta^{14} \mathrm{C}$ values of organic carbon and aluminum content in sinking particles that is consistent over a range of oceanic settings. Together, these findings imply that aged organic carbon associated with lithogenic material from sediment resuspension is responsible for the observed low $\Delta{ }^{14} \mathrm{C}$ values as opposed to other processes such as incorporation of dissolved inorganic carbon or dissolved organic carbon into POC at depth. An estimate based on POC flux-weighted $\Delta^{14} \mathrm{C}$ values shows that about $35 \%$ of sinking POC at the locations studied is derived from resuspended sediment. Our results suggest that resuspension of sediment and its subsequent lateral transport is an important component of the oceanic carbon cycle and should be considered in models of oceanic carbon export and burial.

Citation: Hwang, J., E. R. M. Druffel, and T. I. Eglinton (2010), Widespread influence of resuspended sediments on oceanic particulate organic carbon: Insights from radiocarbon and aluminum contents in sinking particles, Global Biogeochem. Cycles, 24, GB4016, doi:10.1029/2010GB003802.

\section{Introduction}

[2] The photosynthetic fixation of carbon by phytoplankton in the surface ocean, and the subsequent export and burial of a fraction of this carbon in deep waters and underlying sediments is a fundamental component of the global carbon cycle, and drives many oceanic biogeochemical processes [Hedges, 1992]. Understanding the ocean's capacity to take up and sequester $\mathrm{CO}_{2}$ via this "biological pump" [Volk and Hoffert, 1985] is of key importance in gauging responses to recent and future anthropogenically derived increases in atmospheric $\mathrm{CO}_{2}$. A key issue concerns the sinking flux of particulate organic carbon (POC) produced in surface waters, yet the mechanism(s) and efficiency of POC transfer to depth remain only partly understood [Martin et al., 1987; Honjo et al., 2008]. Multiple factors have been proposed to influence carbon export from the surface ocean, and progress is

\footnotetext{
${ }^{\mathrm{T}}$ Woods Hole Oceanographic Institution, Woods Hole, Massachusetts, USA.

${ }^{2}$ POSTECH Ocean Science and Technology Institute, Pohang University of Science and Technology, Pohang, South Korea.

${ }^{3}$ Department of Earth System Science, University of California, Irvine, California, USA.

Copyright 2010 by the American Geophysical Union. 0886-6236/10/2010GB003802
}

being made in understanding the underlying processes, and in reconciling estimates based on different approaches [Dunne et al., 2007]. However, considerable uncertainty remains in models of carbon export. The models are particularly unconstrained for regions overlying, or adjacent to, continental margins where carbon cycling is highly complex and dynamic [Inthorn et al., 2006]; yet these systems are of global importance as regions of high primary productivity and carbon export [Hedges, 1992].

[3] One interesting geochemical characteristic of POC sinking from the surface ocean (which is true for suspended POC as well) is that its radiocarbon content (expressed herein as $\Delta^{14} \mathrm{C}$ values) is generally lower than that expected if primary production in the overlying water column was the sole source of POC [Druffel and Williams, 1990; Druffel et al., 1992]. These low $\Delta^{14} \mathrm{C}$ values imply an additional source of aged (low $\Delta^{14} \mathrm{C}$ ) carbon. Reconciling these lower than expected $\Delta^{14} \mathrm{C}$ values of sinking POC may have important ramifications for models of carbon export, and hold clues concerning organic matter cycling in the ocean.

[4] Adsorption of dissolved organic carbon (DOC) to particles has been suggested as one potential source of this aged carbon [Druffel and Williams, 1990; Hwang et al., 2006]. This could represent a significant removal process of DOC whose average ${ }^{14} \mathrm{C}$ age in the deep oceans is 4000 6500 years $\left(\Delta^{14} \mathrm{C}=-394 \%\right.$ in the Sargasso Sea and $-524 \%$ 
in the North Central Pacific [Druffel et al., 1992; Beaupré and Druffel, 2009]). Incorporation of dissolved inorganic carbon (DIC) by heterotrophic bacteria through an anapleurotic reaction, i.e., a direct uptake of bicarbonate ion through the tricarboxylic acid cycle [Rau et al., 1986], and by autotrophic archaea [Pearson et al., 2001; Ingalls et al., 2006] associated with sinking particles, also represents alternative sources of aged carbon. The contribution from bacterial and archaeal biomass to sinking POC below the euphotic zone is not well understood, but is expected to be spatially variable. Evidence for autotrophic incorporation of DIC stems from $\Delta^{14} \mathrm{C}$ measurements of archaeal lipid biomarkers [Pearson et al., 2001; Ingalls et al., 2006] and from ${ }^{13} \mathrm{C}$-labeling experiments [Wuchter et al., 2003]. Considering that crenarchaeota account for a large fraction of ocean picoplankton, especially in the deep ocean where their abundance is equivalent to or greater than bacteria [Karner et al., 2001], in situ incorporation of DIC to the organic matter pool in the deep ocean may be significant. Additional explanations of lower $\Delta^{14} \mathrm{C}$ values of POC include input of aged terrestrial organic carbon via winds [Eglinton et al., 2002] or rivers [Kao and Liu, 1996; Masiello and Druffel, 2001; Goñi et al., 2005] to the surface waters, and selective preservation and long-term recycling of refractory organic components ultimately derived from primary production [Wang et al., 1998; Hwang and Druffel, 2003, 2006].

[5] Another potential source of aged POC directly supplied to deep waters is from sediment resuspension and lateral particle transport [Nakatsuka et al., 1997; Sherrell et al., 1998; Honda et al., 2000; Hwang et al., 2004, 2008]. Sediments deposited on continental margins are prone to resuspension by dynamic, and often vigorous bottom currents [Rea and Hovan, 1995]. Resuspension of sediment and subsequent lateral transport is evident from several observations, including material fluxes to sediment traps [Honjo et al., 1982; Biscaye et al., 1988; Freudenthal et al., 2001; Smith et al., 2001], bottom and intermediate nepheloid layers [McCave, 1983; McCave et al., 2001; Karakaş et al., 2006; Lam and Bishop, 2008], carbon supply and oxygen consumption in sediments [Jahnke, 1996] ${ }^{14} \mathrm{C}$ ages of suspended and sinking POC [Druffel et al., 1998a; Honda et al., 2000; Hwang et al., 2004, 2008, 2009a, 2009b], aluminum contents of suspended particles [Sherrell et al., 1998], the isotopic and molecular composition of organic matter in deep sea sediments [Benthien and Muller, 2000; Ohkouchi et al., 2002; Mollenhauer et al., 2006], and regional ocean modeling [Karakass et al., 2006]. Sedimentation of aged POC on the continental margin has also been demonstrated by older ages of sedimentary organic matter in the bioturbated layer than expected from the sedimentation rate and mixing of surface sediment with deeper and older sediment [Anderson et al., 1988; Hwang et al., 2005]. If sediment resuspension was responsible for low $\Delta^{14} \mathrm{C}$ values observed even in open ocean settings [Druffel et al., 1992], we would need to invoke large-scale, long-distance lateral POC transport. The existence of such a mechanism would have broad implications for our understanding of biogeochemical cycling of carbon and associated elements in the ocean. Although evidence exists for each of the above processes, the extent to which they contribute to low $\Delta^{14} \mathrm{C}$ values of sinking POC is not well understood.

[6] One way to distinguish the contribution of resuspended sediment from the other processes is to examine the ${ }^{14} \mathrm{C}$ and aluminum ( $\mathrm{Al})$ contents of a given sample. $\mathrm{Al}$ is an effective tracer of resuspended sediment, as it originates from weathered crust and is a major component of sediments delivered to continental margins. Eolian transport and sediment resuspension are two mechanisms by which $\mathrm{Al}$ can be transported to the open ocean and incorporated into sinking particles, in addition to riverine input that has local importance. Here, we use new and published $\Delta^{14} \mathrm{C}$ values and $\mathrm{Al}$ concentrations to show that entrainment of resuspended sediment is the main source of aged carbon into sinking POC.

\section{Data}

[7] $\Delta^{14} \mathrm{C}$ values used in this study were determined using accelerator mass spectrometry (AMS) techniques [ Vogel et al., 1987] with the exception of a few early samples that were measured using beta counting techniques [Druffel et al., 1986, 1998b]. Samples were pretreated to remove inorganic carbon by either addition of $\mathrm{H}_{3} \mathrm{PO}_{4}$ [Druffel and Williams, 1990; Druffel et al., 1992; Anderson et al., 1994; Hwang et al., 2004], rinsing with $\mathrm{HCl}$ [Santschi et al., 1999; Honda et al., 2000; Otosaka et al., 2008], or $\mathrm{HCl}$ fuming [Nakatsuka et al., 1997; Santschi et al., 1999; Hwang et al., 2008, 2009a]. $\Delta^{14} \mathrm{C}$ values have been measured for sinking POC collected at various times, depths and locations (Figure 1a and Table 1). The time span of reported data at a given location ranges from a few years [Hwang et al., 2004] to a few days for a single sample collection [Druffel et al., 1992]. In some cases, samples spanning several months were combined to produce a single data point [Wakeham, 2006]. In Figure 1b, the error bars represent the standard deviation of the mean of the data points; single-point results do not have error bars. The $\Delta^{14} \mathrm{C}$ values of sinking POC are normalized by subtraction of the $\Delta^{14} \mathrm{C}$ values of DIC in the corresponding surface waters. Measured $\Delta{ }^{14} \mathrm{C}$ values of suspended POC collected from the surface waters are also used for this purpose under the assumption that suspended POC in surface water is dominated by in situ primary production. For example, the $\Delta^{14} \mathrm{C}$ values of suspended POC collected at $25 \mathrm{~m}$ in the NE Pacific were $52 \pm 13 \%$ and $59 \pm$ 14\%o in September 1994 and June 1995, respectively, and the corresponding values for DIC were $65 \pm 9 \%$ and $68 \pm 9 \%$ [Druffel et al., 1998a; Masiello et al., 1998].

[8] With the exception of the NE Pacific samples (24 measurements), all $\mathrm{Al}$ data used in this study have been previously published. Al concentrations for NW Atlantic margin [Hwang et al., 2009a], NE Pacific (this study), Canada Basin [Hwang et al., 2008] were measured at Woods Hole Oceanographic Institution by inductively coupled plasma-emission spectroscopy (ICP-ES; Jobin-Yvon Horiba, ULTIMA2), with a detection limit of $22.5 \mu \mathrm{g} \mathrm{g}^{-1}$ and a standard deviation of $5.1 \%$ [Honjo et al., 1995]. Samples were treated following a modified high-temperature alkali fusion method using Alfa Aesar ${ }^{\mathrm{TM}}$ Spectroflux ${ }^{\mathrm{TM}}$ and sequentially dissolving with nitric acid [Ingamells, 1970]. 
USGS MAG1 was used as reference material. Other previously reported results were obtained following a similar method with the exception of the Japan/East Sea samples that were treated with a mixture of $\mathrm{HNO}_{3}, \mathrm{HClO}_{4}$, then $\mathrm{HF}$ [Otosaka et al., 2004]. The Okinawa Trough data were obtained by ICP-ES (JY138 ULTRACE) with a measurement error of less than 7\% [Honda et al., 2000]. The Japan/East Sea data were obtained by ICP-atomic emission spectroscopy
(AES) (SEIKO SPS7700) with an uncertainty smaller than $8 \%$ [Otosaka et al., 2004].

\section{Results}

[9] Figure 1 shows the normalized $\Delta{ }^{14} \mathrm{C}$ values of sinking POC at various locations ranging from continental shelves to the open ocean. The sampling locations vary in terms of total

a)

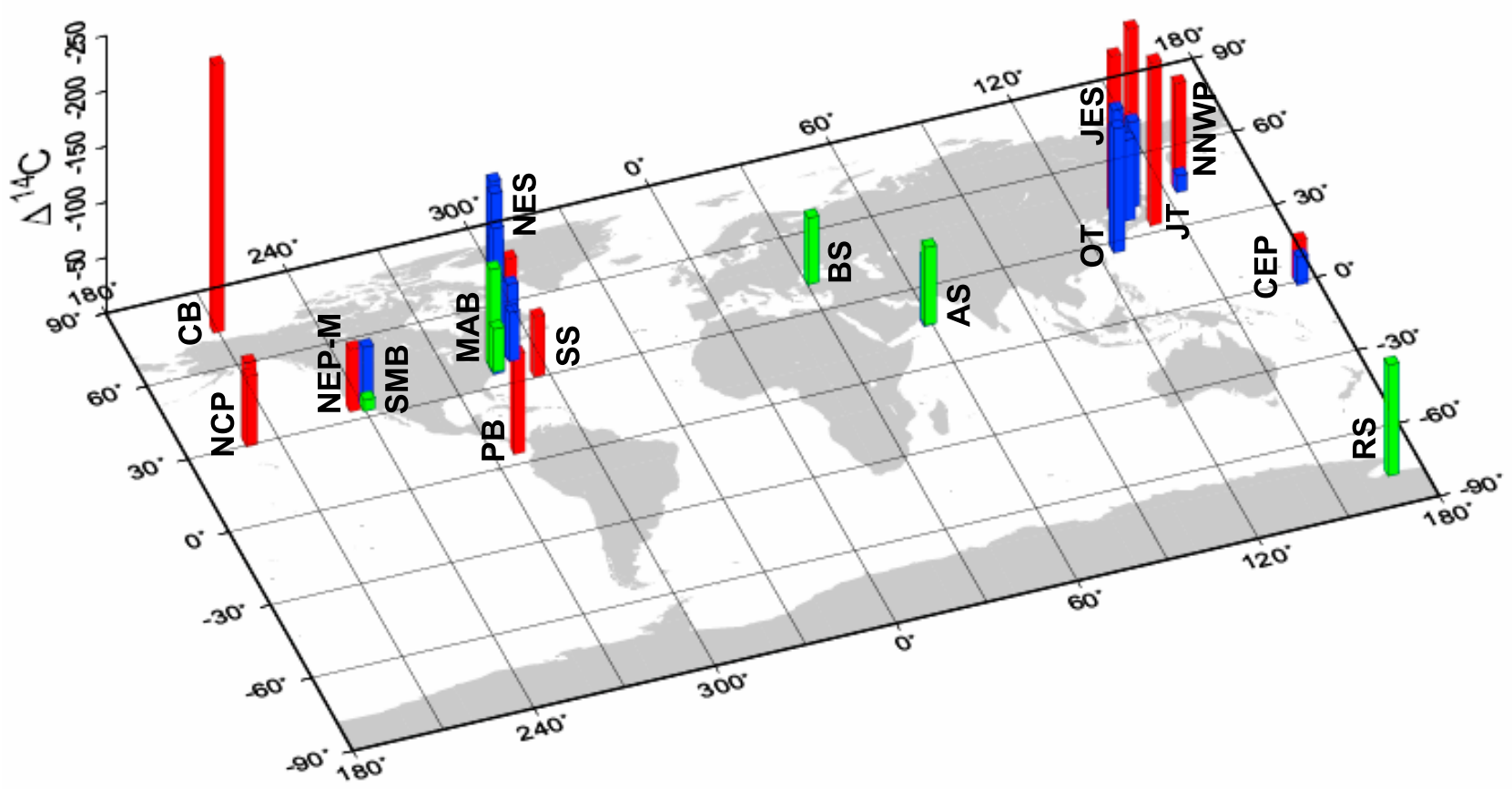

b)

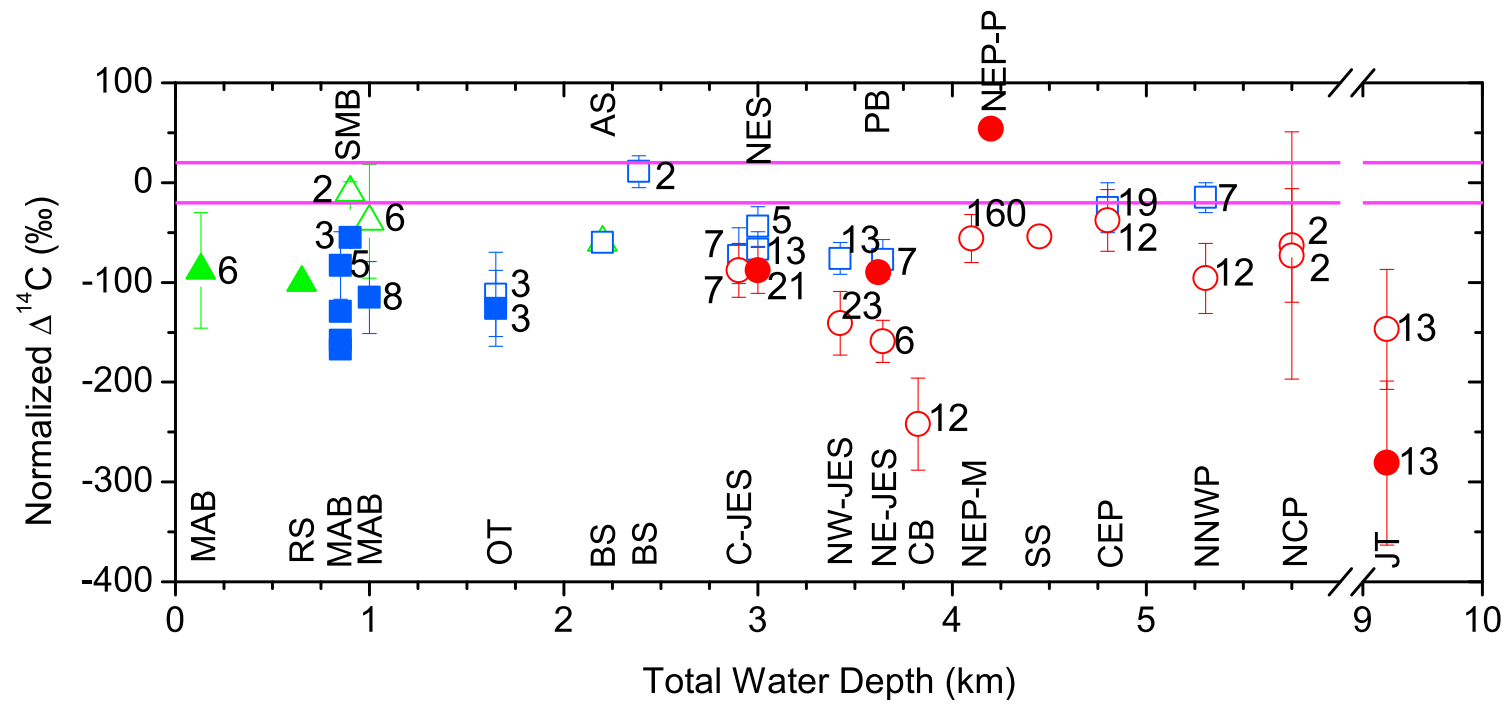

Figure 1 
water depth and height above the seafloor. Only one point at Station $\mathrm{P}$ in the northeast Pacific was significantly higher than the corresponding DIC $\Delta^{14} \mathrm{C}$ values (not plotted in Figure 1). This high value was interpreted by the authors as the contribution of terrestrial POC to that site [Druffel et al., 1986]. Only a few locations on or proximal to continental margins (at $100 \mathrm{~m}$ in the Santa Monica Basin and at $1200 \mathrm{~m}$ in the Black Sea) exhibit normalized $\Delta^{14} \mathrm{C}$ values that fall between $+20 \%$ and $-20 \%$, which conservatively represents the seasonal variability in DIC $\Delta{ }^{14} \mathrm{C}$ values.

[10] The majority of normalized $\Delta^{14} \mathrm{C}$ values were depleted by more than $20 \%$. These low values were observed not only from near the seafloor (solid symbols in Figure 1b) and shallow margin environments, where local resuspension of sediment is expected, but also in open ocean settings such as the abyssal north central Pacific and the central Arctic Ocean (Canada Basin). The lowest normalized $\Delta^{14} \mathrm{C}$ values were observed at the latter site [Hwang et al., 2008] and in the Japan Trench [Nakatsuka et al., 1997]. Other than these extreme values, the normalized $\Delta{ }^{14} \mathrm{C}$ values range between $0 \%$ and $-200 \%$. The average normalized $\Delta^{14} \mathrm{C}$ value for all sites where measured data have been reported is $-87 \pm$ $63 \%$ (the uncertainty reflects the standard deviation of each average value representing each location and depth), and the average value weighted by POC flux is $-95 \%$ (it is not easily doable to estimate the uncertainty of this value, but we believe that it is similar to or slightly larger than $\pm 63 \%$ as determined above), corresponding to a conventional ${ }^{14} \mathrm{C}$ age of 800 years.

\section{Discussion}

[11] At the relatively few locations where both $\Delta^{14} \mathrm{C}$ and $\mathrm{Al}$ contents are available (total 156 data points at 5 locations), the normalized $\Delta^{14} \mathrm{C}$ and $\mathrm{Al}$ values show a strong negative quasi-linear correlation $\left(r^{2}=0.79\right.$ when the Japan/East Sea and Canada Basin data are excluded (Figure 2); see below). This kind of correlation can be expected if the POC is a mixture of two end-members: freshly produced surface POC (normalized $\Delta^{14} \mathrm{C}=0 \%, \mathrm{Al}=0 \%$ ) and aged POC tightly associated with clay and other aluminosilicates that are an important component of lithogenic particles. The most likely source of the lithogenic particles is lateral supply of resuspended oceanic sediments (other potential sources such as eolian input are discussed below). $\Delta{ }^{14} \mathrm{C}$ values also exhibit similar relationships with other tracers of sediments such as excess $\mathrm{Mn}$ in the Japan/East Sea [Otosaka et al., 2008] and Fe on the New England slope $\left(\mathrm{R}^{2}=0.82, \mathrm{n}=39\right.$ (S. J. Manganini and T. I. Eglinton, unpublished data, 2006)), further supporting our argument that the low normalized $\Delta^{14} \mathrm{C}$ values are caused by the presence of resuspended sediment.

[12] Assuming the above is the case, the theoretical maximum $\mathrm{Al}$ content must be close to $8.2 \%$, which represents the average $\mathrm{Al}$ content in the continental crust [Taylor, 1964]. For example, if the POC concentration of this end-member is $5 \%$ (equivalent to $12.5 \%$ as organic matter), then the $\mathrm{Al}$ content is $7.2 \%[=8.2 \times(1-0.125)]$. If resuspended sediment contains other biogenic phases such as $\mathrm{SiO}_{2}$ and $\mathrm{CaCO}_{3}$, the resultant Al content will become lower than this value. However, the contents of these biogenic minerals in resuspended sediment are expected to be small. For example, Al consistently accounts for $7-8 \%$ of total mineral mass for the clay size fraction $(<3 \mu \mathrm{m})$ in coastal sediment on the Washington margin [Keil et al., 1994b], and comprises $7.9 \%$ of resuspended sediment collected from the Minas Basin in the Bay of Fundy, Nova Scotia, Canada [Moran and Moore, 1991].

[13] The mixing curve is determined by both POC concentrations and normalized $\Delta{ }^{14} \mathrm{C}$ values of the end-members. A linear relationship between these two parameters is expected only when POC contents in the two end-members are equal. If the concentration of aged POC is smaller than freshly produced POC, the mixing line will become convex and deviate from a straight line. The data points from three different locations, NW Atlantic margin, NE Pacific, Okinawa Trough, appear to fall along a straight line (Figure 2). The solid line in Figure 2 represents an example mixing line between the two end-members with the same POC concentration but different normalized $\Delta^{14} \mathrm{C}$ values: one end-member with normalized $\Delta^{14} \mathrm{C}=0 \%, \mathrm{POC}=5 \%$, $\mathrm{Al}=0 \%$ and the other with normalized $\Delta^{14} \mathrm{C}=-182 \%$, $\mathrm{POC}=5 \%$, and the resultant $\mathrm{Al}=7.18 \%$. The dotted line represents another example of two end-member mixing of

Figure 1. (a) A map showing the location of sinking POC samples and their average normalized $\Delta^{14} \mathrm{C}$ values. The $\Delta^{14} \mathrm{C}$ values are normalized to the corresponding values of dissolved inorganic carbon or those of suspended POC in the surface waters. Samples are categorized into three groups depending on the sampling depth: $<500 \mathrm{~m}$ (green), $500 \mathrm{~m} \ll 2000 \mathrm{~m}$ (blue), and $>2000 \mathrm{~m}$ (red). Except for one sample (54\%, at Station P in the northeast Pacific, not plotted), all samples exhibit negative average normalized $\Delta^{14} \mathrm{C}$ values. (b) Normalized $\Delta^{14} \mathrm{C}$ values (\%o) of sinking POC plotted with respect to the total water depth. The symbols represent average values of each time series data set (numbers by the symbols represent the number of data points). The error bars represent the standard deviation of $\Delta^{14} \mathrm{C}$ values. No error bars are provided when only a single datum is available. The horizontal bars represent the range of surface normalized $\Delta^{14} \mathrm{C}$ values if in situ production were the only source of sinking POC considering the uncertainties and seasonal fluctuation in surface DIC $\Delta^{14} \mathrm{C}$ values. Depending on the sampling depth, the data points are categorized into upper ocean $(<500 \mathrm{~m}$; triangles $)$, mesopelagic zone $(500 \ll 2000 \mathrm{~m}$; squares), and bathypelagic zone $(>2000 \mathrm{~m}$; circles). Solid symbols represent the samples collected within $500 \mathrm{~m}$ from the bottom. Letters below or above the symbols represent the names of the sites. Abbreviations for the site names are as follows: AS, Arabian Sea; BS, Black Sea; CB, Canada Basin; CEP, central Equatorial Pacific; C-JES, central Japan/East Sea; JT, Japan Trench; MAB, Middle Atlantic Bight; NCP, north central Pacific; NE-JES, northeast Japan/East Sea; NEP-M, northeast Pacific-Station M; NEP-P, northeast Pacific-Station P; NES, New England slope; NNWP, north-northwest Pacific; NW-JES, northwest Japan/East Sea; OT, Okinawa Trough; PB, Panama Basin; RS, Ross Sea; SMB, Santa Monica Basin; SS, Sargasso Sea. 
Table 1. $\triangle^{14} \mathrm{C}$ Values of Sinking POC Normalized to the Corresponding Values of Dissolved Inorganic Carbon or Those of Suspended POC in the Surface Waters

\begin{tabular}{|c|c|c|c|c|c|c|c|c|c|}
\hline Site & Latitude & Longitude & $\begin{array}{l}\text { Sampling } \\
\text { Year }\end{array}$ & $\begin{array}{l}\text { Water } \\
\text { Depth } \\
(\mathrm{m})\end{array}$ & $\begin{array}{c}\text { Surface } \\
\text { Water } \\
\Delta^{14} \mathrm{C}(\%)\end{array}$ & $\begin{array}{l}\text { Trap } \\
\text { Depth } \\
(\mathrm{m})\end{array}$ & $\begin{array}{c}\text { Normalized } \\
\Delta^{14} \mathrm{C} \% \\
\text { (Number of Data) }\end{array}$ & $\begin{array}{c}\text { Average } \\
\text { POC Flux } \\
\left(\mathrm{mg} \mathrm{C} \mathrm{m}^{-2} \mathrm{~d}^{-1}\right)\end{array}$ & $\begin{array}{c}\text { Average } \\
\text { Al (\%) } \\
\text { (Number of Data) }\end{array}$ \\
\hline $\begin{array}{l}\text { Canada Basin } \\
\quad[\text { Hwang et al., 2008] }\end{array}$ & 75.0 & -150.0 & 2004-2005 & 3824 & $\begin{array}{c}25 \\
\text { [Jones et al., } \\
\text { 1994] }\end{array}$ & 3067 & $-242 \pm 46(12)$ & 0.6 & $6.7 \pm 0.7(21)$ \\
\hline $\begin{array}{l}\text { New England slope } \\
\quad[\text { Hwang et al., 2009a] }\end{array}$ & 39.5 & -68.3 & 2004-2005 & 3000 & $67^{\mathrm{a}}$ & $\begin{array}{c}968 \\
1976 \\
2938\end{array}$ & $\begin{array}{l}-44 \pm 20(5) \\
-67 \pm 18(13) \\
-88 \pm 23(21)\end{array}$ & $\begin{array}{l}16.6 \\
9.3 \\
10.0\end{array}$ & $\begin{array}{l}2.0 \pm 1.0(11) \\
2.4 \pm 1.1(17) \\
3.4 \pm 0.8(21)\end{array}$ \\
\hline $\begin{array}{l}\text { NE Pacific Station P } \\
\text { [Druffel et al., 1986] }\end{array}$ & 50.0 & -145.0 & 1983 & 4200 & 74 & 3800 & $54(1)$ & 8.8 & \\
\hline $\begin{array}{l}\text { North central Pacific } \\
\text { [Druffel et al., 1992] }\end{array}$ & 31.0 & -159.0 & 1985,1987 & 5750 & 121 & $\begin{array}{l}4120 \\
4200 \\
5120\end{array}$ & $\begin{array}{l}-63 \pm 57(2) \\
-73 \pm 124(2)\end{array}$ & $\begin{array}{l}2.5^{\mathrm{b}} \\
2.2^{\mathrm{b}}\end{array}$ & \\
\hline $\begin{array}{l}\text { Sargasso Sea } \\
\quad[\text { Druffel et al., 1992] }\end{array}$ & 31.8 & -63.5 & 1990 & 4450 & 120 & 3200 & $-54(1)$ & $1.6^{\mathrm{b}}$ & \\
\hline $\begin{array}{l}\text { Panama Basin } \\
\text { [Druffel et al., 1998b] }\end{array}$ & 5.3 & -82.0 & 1984 & 3620 & 88 & 3354 & $-91(1)$ & $8.1^{\mathrm{b}}$ & \\
\hline $\begin{array}{l}\text { Santa Monica Basin } \\
{[\text { Druffel and }} \\
\text { Williams, 1990] }\end{array}$ & 33.8 & -118.8 & 1986-1987 & 900 & 96 & 100 & $-10 \pm 11(2)$ & $\begin{array}{c}31.0 \\
{[\text { Nelson }} \\
\text { et al., } 1987] \\
24.7 \\
{[\text { Nelson }} \\
\text { et al., 1987] }\end{array}$ & \\
\hline $\begin{array}{l}\text { Ross Sea } \\
\text { [Wakeham, 2006] }\end{array}$ & -77.0 & 170.0 & 1997-1998 & 650 & -100 & 230 & $-100(1)$ & $\begin{array}{c}45.4 \\
{[\text { Dunbar }} \\
\text { et al., } 1998]\end{array}$ & \\
\hline $\begin{array}{l}\text { Black Sea } \\
\quad \text { [Wakeham, 2006] }\end{array}$ & 42.0 & 32.0 & 1985-1986 & 2200 & 70 & $\begin{array}{l}250 \\
1000\end{array}$ & $-60(1)$ & $\begin{array}{c}11.2 \\
{[\text { Hay }} \\
\text { et al., 1990] }\end{array}$ & \\
\hline $\begin{array}{l}\text { Arabian Sea MS-1, } \\
\text { MS-3 } \\
\text { [Wakeham, 2006] }\end{array}$ & 17.0 & 59.0 & 1994-1995 & $\begin{array}{l}1500 \\
2900\end{array}$ & 70 & $\begin{array}{l}500 \\
1500\end{array}$ & $-60(1)$ & $15.4^{\mathrm{c}}$ & \\
\hline $\begin{array}{l}\text { Okinawa Trough } \\
\quad[\text { Honda et al., 2000] }\end{array}$ & 27.4 & 126.7 & 1993 & 1650 & 105 & $\begin{array}{l}1000 \\
1500\end{array}$ & $\begin{array}{l}-112 \pm 42(3) \\
-126 \pm 38(3)\end{array}$ & $\begin{array}{l}4.8 \\
4.7\end{array}$ & $\begin{array}{c}4.8 \pm 0.7(42) \\
5.1 \pm 0.9(3)\end{array}$ \\
\hline $\begin{array}{l}\text { Northwest Pacific } \\
\text { NNWP-02 } \\
\text { [Nakatsuka } \\
\text { et al., 1997] }\end{array}$ & 44 & 155 & 1989-1990 & 5305 & $-44^{\mathrm{d}}$ & $\begin{array}{l}1335 \\
4785\end{array}$ & $\begin{array}{l}-15 \pm 15(7) \\
-96 \pm 35(12)\end{array}$ & $\begin{array}{l}5.1 \\
4.5\end{array}$ & \\
\hline $\begin{array}{l}\text { Japan Trench, JT-06 } \\
\text { [Nakatsuka } \\
\text { et al., 1997] }\end{array}$ & 34.2 & 142.0 & 1990-1991 & 9200 & $27^{\mathrm{e}}$ & $\begin{array}{l}4789 \\
8789\end{array}$ & $\begin{array}{l}-147 \pm 60(13) \\
-281 \pm 82(13)\end{array}$ & $\begin{array}{l}3.4 \\
3.3\end{array}$ & \\
\hline $\begin{array}{l}\text { Central Equatorial } \\
\text { Pacific } 175 \mathrm{E} \\
{[\text { Nakatsuka }} \\
\text { et al., 1997] }\end{array}$ & 0.0 & 175.0 & 1992-1993 & 4800 & $100^{\mathrm{f}}$ & $\begin{array}{l}1700 \\
4220\end{array}$ & $\begin{array}{l}-25 \pm 25(19) \\
-38 \pm 31(12)\end{array}$ & $\begin{array}{l}1.7 \\
1.3\end{array}$ & \\
\hline $\begin{array}{l}\text { Northeast Pacific } \\
\text { Station M } \\
\text { [Hwang et al., 2004] }\end{array}$ & 34.8 & -123.0 & 1993-1998 & 4100 & $\begin{array}{c}60 \\
{[\text { Masiello }} \\
\text { et al., 1998] }\end{array}$ & 3450 & $-56 \pm 24(160)$ & 3.6 & $2.8 \pm 0.8(24)$ \\
\hline $\begin{array}{l}\text { Middle Atlantic Bight } \\
\text { [Santschi } \\
\text { et al., 1999] }\end{array}$ & 36.1 & -74.7 & 1993 & 850 & $\begin{array}{c}60 \\
{[\text { Bauer }} \\
\text { et al., 2002] }\end{array}$ & $\begin{array}{l}825 \\
770 \\
650 \\
700\end{array}$ & $\begin{array}{c}-158(1) \\
-167(1) \\
-129(1) \\
-83 \pm 34(5)\end{array}$ & $\begin{array}{l}71.6 \\
55.4 \\
46.9 \\
24.7\end{array}$ & \\
\hline $\begin{array}{l}\text { Middle Atlantic Bight, } \\
\text { M-10 [Anderson et al., } \\
\text { 1994] }\end{array}$ & 36.9 & -74.6 & 1988-1989 & 1000 & $35^{\mathrm{g}}$ & $\begin{array}{l}130 \\
990\end{array}$ & $\begin{array}{l}-39 \pm 57(6) \\
-115 \pm 36(8)\end{array}$ & $\begin{array}{l}12.0 \\
65.0\end{array}$ & \\
\hline $\begin{array}{l}\text { Middle Atlantic Bight, } \\
\text { M-8 [Anderson et al., } \\
\text { 1994] }\end{array}$ & 36.9 & -74.7 & 1988-1989 & 130 & $35^{\mathrm{g}}$ & 120 & $-88 \pm 58(6)$ & 75.0 & \\
\hline $\begin{array}{c}\text { Northwest Japan/East Sea } \\
\text { [Otosaka et al., 2008] }\end{array}$ & 41.2 & 132.4 & $2000-2002$ & 3424 & $\begin{array}{c}61 \\
\text { [Aramaki } \\
\text { et al., 2007] }\end{array}$ & $\begin{array}{c}927 \\
2746\end{array}$ & $\begin{array}{l}-76 \pm 16(13) \\
-141 \pm 32(23)\end{array}$ & $\begin{array}{l}30.9 \\
16.1\end{array}$ & $\begin{array}{l}2.8 \pm 0.9(27)^{\mathrm{h}} \\
3.8 \pm 1.3(49)^{\mathrm{h}}\end{array}$ \\
\hline $\begin{array}{l}\text { Northeast Japan/East Sea } \\
\text { [Otosaka et al., 2008] }\end{array}$ & 42.5 & 138.5 & 2000-2001 & 3642 & $\begin{array}{c}56 \\
\text { [Aramaki } \\
\text { et al., 2007] }\end{array}$ & $\begin{array}{l}1057 \\
3043\end{array}$ & $\begin{array}{l}-77 \pm 20(7) \\
-159 \pm 21(6)\end{array}$ & $\begin{array}{l}11.1 \\
4.5\end{array}$ & $\begin{array}{l}1.8 \pm 0.2(26)^{\mathrm{h}} \\
3.3 \pm 0.8(26)^{\mathrm{h}}\end{array}$ \\
\hline
\end{tabular}


Table 1. (continued)

\begin{tabular}{|c|c|c|c|c|c|c|c|c|c|}
\hline Site & Latitude & Longitude & $\begin{array}{l}\text { Sampling } \\
\text { Year }\end{array}$ & $\begin{array}{l}\text { Water } \\
\text { Depth } \\
\text { (m) }\end{array}$ & $\begin{array}{c}\text { Surface } \\
\text { Water } \\
\Delta^{14} \mathrm{C}(\%)\end{array}$ & $\begin{array}{l}\text { Trap } \\
\text { Depth } \\
\text { (m) }\end{array}$ & $\begin{array}{c}\text { Normalized } \\
\Delta^{14} \mathrm{C} \% \text { o } \\
\text { (Number of Data) }\end{array}$ & $\begin{array}{c}\text { Average } \\
\text { POC Flux } \\
\left(\mathrm{mg} \mathrm{C} \mathrm{m}^{-2} \mathrm{~d}^{-1}\right)\end{array}$ & $\begin{array}{c}\text { Average } \\
\text { Al }(\%) \\
\text { (Number of Data) }\end{array}$ \\
\hline $\begin{array}{l}\text { Central Japan/East Sea } \\
\text { [Otosaka et al., 2008] }\end{array}$ & 38.0 & 135.0 & $2000-2001$ & 2900 & $\begin{array}{c}70 \\
{[\text { Aramaki }} \\
\text { et al., 2007] }\end{array}$ & $\begin{array}{l}1175 \\
2100\end{array}$ & $\begin{array}{l}-73 \pm 28(7) \\
-88 \pm 27(7)\end{array}$ & $\begin{array}{l}27.1 \\
19.8\end{array}$ & $\begin{array}{l}2.7 \pm 0.9(13)^{\mathrm{h}} \\
3.6 \pm 0.9(13)^{\mathrm{h}}\end{array}$ \\
\hline $\begin{array}{l}\text { Black Sea } \\
\text { [Jones and Gagnon, } \\
\text { 1994] }\end{array}$ & 43.0 & 34.0 & 1988 & 2386 & 87.5 & 1200 & $11 \pm 16(2)$ & $\begin{array}{c}13.1 \\
{[\text { Hay et al., }} \\
\text { 1990] }\end{array}$ & \\
\hline \multicolumn{10}{|c|}{$\begin{array}{l}{ }^{\mathrm{a}} \Delta^{14} \mathrm{C} \text { value of suspended POC collected from the ship's clean seawater intake [Hwang et al., 2009b]. } \\
{ }^{\mathrm{b}} \mathrm{POC} \text { fluxes at each sampling depth were estimated based on the data of François et al. [2002] and Martin et al.'s [1987] equation. } \\
\text { c The average value of POC flux at } 808 \mathrm{~m} \text { and } 999 \mathrm{~m} \text { at Station M-1, and at } 746 \mathrm{~m} \text { and } 858 \mathrm{~m} \text { at Station M-3 [Honjo et al., 1999]. } \\
{ }^{\mathrm{d}} \Delta^{14} \mathrm{C} \text { value of suspended POC collected at } 50 \mathrm{~m} \text { in } 1985 \text { [Nakatsuka et al., 1997]. } \\
\mathrm{e}^{\mathrm{e}} \Delta^{14} \mathrm{C} \text { value of suspended POC collected at } 200 \mathrm{~m} \text { in } 1987 \text { [Nakatsuka et al., 1997]. } \\
{ }_{\mathrm{f}} \text { An assumed } \Delta^{14} \mathrm{C} \text { value based on the work by Levin and Hessheimer [2000]. } \\
{ }^{\mathrm{g}} \text { The highest } \Delta^{14} \mathrm{C} \text { value of sinking POC captured by a } 130 \mathrm{~m} \text { trap [Anderson et al., 1994]. } \\
\text { h Japan/East Sea aluminum data are from Otosaka et al. [2004]. }\end{array}$} \\
\hline
\end{tabular}

fresh POC with organic matter of an older age and a lower POC concentration $\left(\Delta^{14} \mathrm{C}=-274 \%\right.$, POC $\left.=3 \%\right)$. In this case, a $\Delta^{14} \mathrm{C}$ value of $-274 \%$ represents the normalized value of $-214 \%$ to the surface DIC $\Delta^{14} \mathrm{C}$ value of $+60 \%$ (regarding the choice of $-214 \%$, see discussion below). The choice for POC concentration of aged organic matter is somewhat arbitrary, lying between that of the average sinking POC (5\%) and lower values for surface sediments. POC contents of sinking particles do not vary markedly in the deep ocean below mesopelagic/bathypelagic boundary [Armstrong et al., 2001], and averages 5.0 $\pm 2.3 \%$ for sinking particles intercepted at depths greater than $1000 \mathrm{~m}(\mathrm{n}=2083$, data compiled by S. Honjo and R. Francois; http://www1. whoi.edu/datasys/SMP/Honjo/sed traps.htm). This value decreases only slightly to $4.5 \pm 1 . \overline{7} \%(\mathrm{n}=1425)$ when data for samples deeper than $2000 \mathrm{~m}$ are used (data compiled by S. Honjo and R. Francois; http://www1.whoi.edu/datasys/ SMP/Honjo/sed_traps.htm). POC contents of resuspended sediments are expected to have high spatial variability. They are likely to be generally higher than those of underlying sediments because fine-grained particles exhibit higher carbon loadings and low-density organic matter-mineral aggregates are likely to be preferentially resuspended relative to other components such as calcareous or siliceous biogenic debris [Thomsen and Gust, 2000]. For example, the $\mathrm{OC}$ content of the clay $(<3 \mu \mathrm{m})$ fraction (OC, 3-6\%) in Washington margin sediments is higher than those of corresponding bulk sediment (1-3\%) because of their higher mineral surface areas [Mayer, 1994; Keil et al., 1994a; Keil and Cowie, 1999; Coppola et al., 2007]. Similarly, the OC content of suspended particles collected within $1 \mathrm{~m}$ of the seafloor in the Gulf of Maine [Townsend et al., 1992], where sediment resuspension is prominent [Bothner et al., 1981; Pilskaln, 2006], was $4.0 \pm 1.6 \%(\mathrm{n}=19)$; this is close to that of sinking POC but significantly higher than those of underlying sediments (1-2\% [Charette et al., 2001]). If POC contents in resuspended sediments are comparable to those in sinking particles, a virtually linear correlation would be obtained between normalized $\Delta^{14} \mathrm{C}$ values and $\mathrm{Al}$ content.

[14] Data from the deep Canada Basin exhibiting the highest $\mathrm{Al}$ concentrations fall below the linear mixing line because of extremely low normalized $\Delta^{14} \mathrm{C}$ values and/or low POC concentrations of the resuspended sediment endmember. The data from the shallow Canada Basin exhibit more scatter than at other locations, potentially because the trap drifted over widely different water depths from a few hundreds to thousands of meters [Macdonald et al., 2002], intercepting resuspended sediment that varies in provenance [Honjo et al., 2010].

[15] Dissolved Al scavenged to particles [Murray and Leinen, 1996] and eolian inputs constitute other potential

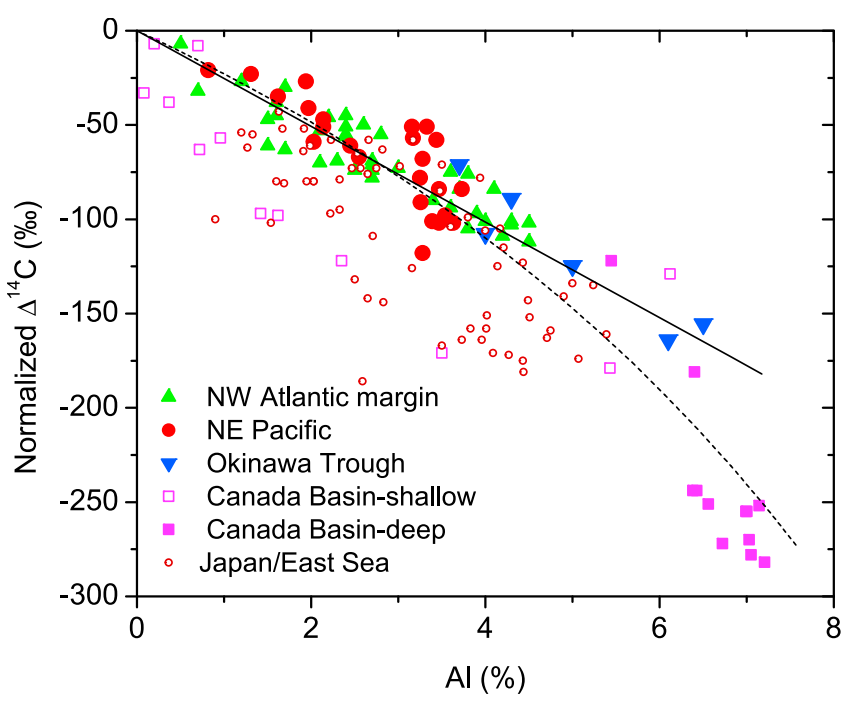

Figure 2. Correlation between normalized $\Delta^{14} \mathrm{C}$ values of POC and aluminum contents in sinking particles. The solid line represents an example of two end-member mixing between recently produced organic matter $\left(\Delta^{14} \mathrm{C}=0 \%\right.$, $\mathrm{POC}=5 \%$ ) and aged OC associated with resuspended sediment $\left(\Delta^{14} \mathrm{C}=-182 \%\right.$, POC $\left.=5 \%\right)$. The dotted line represents a mixing of fresh organic matter with organic matter of an older age and a lower POC content $\left(\Delta^{14} \mathrm{C}=-274 \%\right.$, $\mathrm{POC}=3 \%$, see text regarding the choice of these values). As the POC concentration deviates from the fresh POC value $(5 \%)$ toward lower values, the line becomes more convex. 
sources of particulate Al. Contributions from scavenged Al are locally important only when particulate $\mathrm{Al}$ contents are extremely small, such as in the Equatorial Pacific [Murray and Leinen, 1996]. Collier et al. [2000] used the ratio between $\mathrm{Ti}$ and $\mathrm{Al}$ of sinking particles in the Ross Sea to show that absorbed $\mathrm{Al}$ in the water is insignificant at that location. Eolian input can be important locally and seasonally. For example, locations proximal to continents and under the trajectory of major dust tracts, such as Okinawa Trough and Japan/East Sea, receive significant Al fluxes from atmospheric deposition, with annual average inputs exceeding $2 \mathrm{mg} \mathrm{m}^{-2} \mathrm{~d}^{-1}$ [Duce et al., 1991; Measures and Vink, 2000]. Eolian input of Al may account for up to 7-15\%, $12 \%, 20-39 \%, 20-50 \%$ of the observed Al flux in the NW Atlantic (New England slope), northeast Pacific off the coast of California, Okinawa Trough, and Japan/East Sea, respectively (estimated from the data by Measures and Vink [2000], Minakawa and Watanabe [1998], and Suzuki and Tsunogai [1988]). It is challenging to assess the influence of eolian supply of OC on sinking POC because there is no equivalent data on eolian supply of $\mathrm{OC}$ at the study sites. However, considering that eolian supply of OC comprises less than $1 \%$ of in situ production in surface waters, even on the continental margins proximal to the major sources of eolian dust, OC delivered by this mode of supply is likely to be insignificant. Studies of the biogeochemical and $\mathrm{C}$ isotopic properties of aerosol OC [e.g., Gustafsson et al., 2009] and on the processes that influence the fate of eolian OC following deposition to the surface ocean will be necessary to further address this issue. The normalized $\Delta^{14} \mathrm{C}$ value of sinking POC could either be lowered or raised depending on the $\Delta^{14} \mathrm{C}$ value of eolian POC. This additional OC source is likely to cause deviation from, or higher scatter in relation to the mixing line, such as is observed for data from the Japan/ East Sea [Otosaka et al., 2008]. However, for the seasonally ice-covered Arctic Ocean regions including portions of the central Canada Basin [Hwang et al., 2008], this source is expected to be negligible. Even when ice started to melt and release dust accumulated on the ice (suggested by an abrupt increase in normalized $\Delta^{14} \mathrm{C}$ ), Al content virtually remained unchanged [Hwang et al., 2008].

[16] The y intercept of the trend line (i.e., when Al content is zero) should indicate the influence of processes other than the incorporation of resuspended sediment and potentially, eolian dust. Excluding the Canada Basin and Japan/East Sea data, the $y$ intercept of the linear regression is $-8 \pm 5 \%$, which is not significantly different from $0 \%$ considering the uncertainty of $\Delta^{14} \mathrm{C}$ measurements and the normalization method. This implies that incorporation of DIC and DOC into sinking POC via microbial or physicochemical processes may be smaller than previously suggested [Rau et al., 1986; Druffel and Williams, 1990; Pearson et al., 2001; Hwang et al., 2006; Ingalls et al., 2006]. The y intercept also enables upper limits to be placed on the contribution from each potential source. To provide estimates for the upper limits, a $20 \%$ decrease in normalized $\Delta^{14} \mathrm{C}$ (a conservative uncertainty for seasonal variability of DIC $\Delta^{14} \mathrm{C}$ ), was used for the overall effect of these other sources. In a model case where the $\Delta^{14} \mathrm{C}$ value for freshly produced POC is $+60 \%$, that for deep water DIC is between -80 and $-220 \%$, and that for deep
DOC is between -400 and $-550 \%$ [Druffel et al., 1992; Beaupré and Druffel, 2009], the upper limits for the contribution from DIC and DOC to sinking POC are between 7 and $14 \%$, and between 3 and 4\%, respectively. The contribution of each individual process is likely smaller than these values considering that incorporation of both DIC and DOC may occur simultaneously. However, it should also be noted that isotopic heterogeneity of DOC [Loh et al., 2004] may cause uncertainty in this estimation. For example, if bacteria preferentially uptake young DOC components [Cherrier et al., 1999], this might imply that estimates of DOC incorporation onto POC are too low.

[17] Acknowledging that the data coverage is currently very sparse and that additional measurements are needed, we derive a tentative estimate of the global contribution of resuspended sediment to sinking POC using the average POC flux-weighted decrease in normalized $\Delta^{14} \mathrm{C}(95 \%)$. The assignment of a global average $\Delta^{14} \mathrm{C}$ value for the resuspended sediment end-member represents a major source of uncertainty, and ideally, this should be determined for each specific location. Here, we used ${ }^{14} \mathrm{C}$ measurements on core top sediment $(0-1 \mathrm{~cm})$ at 24 locations on the NW Atlantic margin that range in water depth from 280 and $3865 \mathrm{~m}$ in order to derive an average $\Delta^{14} \mathrm{C}$ value $(-214 \pm 59 \%$ ) that we adopted as representative for resuspended sediment. Based on this value, the $95 \%$ difference in $\Delta^{14} \mathrm{C}$ between fluxweighted POC and average surface water DIC (60\%) implies that $35 \%( \pm 13 \%$ propagated error $)$ of sinking POC is derived from resuspended sediment. This may represent a minimum value because the sedimentary component that is prone to resuspension is composed of fresher, fluffy organic matterrich aggregates and other detrital materials residing at or near the sediment-water interface that would likely have higher $\Delta^{14} \mathrm{C}$ values [Wang et al., 1996]. This inference is supported by the observation that NW Atlantic margin, NE Pacific, Okinawa Trough data are well represented by the solid mixing line in Figure 2, with an end-member $\Delta^{14} \mathrm{C}$ value of $-182 \%$ (corresponding to the unnormalized $\Delta^{14} \mathrm{C}$ value of $-122 \%$ ), significantly higher than $-214 \%$. If this is the case, we estimate that the contribution of resuspended sediment could be greater than $50 \%$. In either case, the results imply that the current estimate of export production based on direct POC flux measurements is biased toward higher values.

[18] Our findings show that resuspension of sediment and subsequent lateral advection is widespread in the ocean, especially over, or proximal to, the continental margins. Lithogenic particles originating from the continent are transported to the continental margin and further into the deep ocean interior via hydrodynamic processes. This phenomenon, termed "hemipelagic sedimentation" [Rea and Hovan, 1995], is important for the supply of minerals to the ocean basins. Our observation that lithogenic particles are tightly associated with aged POC implies that the role of hemipelagic sedimentation in POC cycling should be reevaluated and better quantified, especially with respect to carbon export from the continental shelves to the interior ocean. Export of DIC alone has been described in the context of the continental shelf pump hypothesis [Tsunogai et al., 1999]. It seems clear that we must also consider the continental shelf pump in terms of POC (and likely DOC) export. 
[19] Another important implication of our results concerns the role of lithogenic particles in vertical transport of POC [Dunne et al., 2007]. Calcium carbonate has been found to be the major ballast mineral of POC in open ocean settings [François et al., 2002; Klaas and Archer, 2002], whereas lithogenic particles have hitherto been considered to play only a minor role, primarily because lithogenic fluxes in the deep sea are small [François et al., 2002]. However, this paradigm may not hold for margin-proximal sites with abundant sources and higher fluxes of lithogenic particles, and where normalized $\Delta^{14} \mathrm{C}$ values are low. The high POC fluxes that typify margin settings may be supported to a significant degree by laterally supplied lithogenic particles and associated OC. Finally, the biogeochemical character of $\mathrm{OC}$ entrained with resuspended sediment likely differs from that of freshly produced POC because it has experienced more extensive degradation and because of its intimate association with the mineral surfaces [Keil et al., 1994a; Mayer, 1994; Keil and Cowie, 1999; Coppola et al., 2007]. These differences may influence its fate during transport and sedimentation, and the biogeochemical properties of resuspended sedimentary OC may be further altered by water column processes. Incorporation of these factors into our understanding of the oceanic carbon cycle will require models that accommodate lateral POC transport as well as vertical settling of POC to the deep ocean, and will also need to account for the potentially different OC loading and reactivity of these inputs.

\section{Summary and Conclusions}

[20] Numerous prior studies have provided evidence for the resuspension and subsequent lateral transport of sediments in a range of marine environments, however, the ubiquity and overall significance of this process in terms of organic matter cycling in the oceans has remained unclear. In this study, new insights have been gained from bringing together disparate observations and data sets on the contents of $\mathrm{Al}$ and ${ }^{14} \mathrm{C}$ within sinking particles intercepted by sediment traps. The relationship between $\mathrm{Al}$ content and normalized $\Delta^{14} \mathrm{C}$ is widespread and the overall slope of the relationship is remarkably constant, indicating that this phenomenon is global and consistent over a wide range of oceanic settings. The near-zero y intercept for the mixing lines implies that aged organic carbon associated with lithogenic material from sediment resuspension is responsible for the observed low normalized $\Delta^{14} \mathrm{C}$ values (as opposed to other processes such as incorporation of dissolved inorganic carbon or dissolved organic carbon into POC at depth). Using a compilation of data sets of $\Delta^{14} \mathrm{C}$ and POC flux, we estimate that $35 \%$ of sinking $\mathrm{POC}$ may derive from resuspended sediments globally; this proportion may be even higher depending on the choice of isotopic end-member for this calculation.

[21] Our results suggest that sediment remobilization and redistribution is an important component of the oceanic carbon cycle and should be considered in models of oceanic carbon export and burial. Given that particles intercepted by sediment traps have mostly been assumed to originate from the overlying water column, these findings imply that the vertical component of the flux is overestimated whereas continental margin export is underestimated. The role of the continental margins in exporting POC to the interior ocean should be carefully reevaluated and better quantified. In addition, the influence of sediment remobilization processes on the biogeochemical properties of resuspended POC and its consequences for the bathypelagic food web and for OC burial in deep ocean sediments requires further examination.

[22] Acknowledgments. We thank Steve Manganini for sample collection and aluminum analyses, Daniel Montluçon for guidance in laboratory work, Sheila Griffin for sample collection, and staff at the National Ocean Sciences AMS facility for carbon isotope measurements. We specially thank Stuart Wakeham for kindly allowing us to use his unpublished ${ }^{14} \mathrm{C}$ results. We thank the Associate Editor and the reviewers for their helpful comments. This research was funded by the NSF Ocean Sciences Division (Chemical Oceanography program) and by the Ocean and Climate Change Institute and Arctic Research Initiative at the Woods Hole Oceanographic Institution.

\section{References}

Anderson, R. F., R. F. Bopp, K. O. Buesseler, and P. E. Biscaye (1988), Mixing of particles and organic constituents in sediments from the continental shelf and slope off Cape Cod: SEEP-I results, Cont. Shelf Res., 8 , 925-946, doi:10.1016/0278-4343(88)90082-9.

Anderson, R. F., G. T. Rowe, P. F. Kemp, S. Trumbore, and P. E. Biscaye (1994), Carbon budget for the mid-slope depocenter of the Middle Atlantic Bight, Deep Sea Res., Part II, 41, 669-703, doi:10.1016/0967-0645 (94)90040-X.

Aramaki, T., T. Senjyu, O. Togawa, S. Otosaka, T. Suzuki, T. Kitamura, H. Amano, and Y. N. Volkov (2007), Circulation in the northern Japan Sea studied chiefly with radiocarbon, Radiocarbon, 49, 915-924.

Armstrong, R. A., C. Lee, J. I. Hedges, S. Honjo, and S. G. Wakeham (2001), A new, mechanistic model for organic carbon fluxes in the ocean based on the quantitative association of POC with ballast minerals, Deep Sea Res., Part II, 49, 219-236, doi:10.1016/S0967-0645(01)00101-1.

Bauer, J. E., E. R. M. Druffel, D. M. Wolgast, and S. Griffin (2002), Temporal and spatial variability of sources and cycling of DOC and POC in the northwest Atlantic continental margin, Deep Sea Res., Part II, 49, 4387-4419, doi:10.1016/S0967-0645(02)00123-6.

Beaupré, S. R., and E. R. M. Druffel (2009), Constraining the propagation of bomb-radiocarbon through the dissolved organic carbon (DOC) pool in the northeast Pacific Ocean, Deep Sea Res., Part I, 56, 1717-1726, doi:10.1016/j.dsr.2009.05.008.

Benthien, A., and P. J. Muller (2000), Anomalously low alkenone temperatures caused by lateral particle and sediment transport in the Malvinas Current region, western Argentine Basin, Deep Sea Res., Part I, 47, 2369-2393, doi:10.1016/S0967-0637(00)00030-3.

Biscaye, P. E., R. F. Anderson, and L. D. Deck (1988), Fluxes of particles and constituents to the eastern United States continental slope and rise: SEEP-I, Cont. Shelf Res., 8, 855-904, doi:10.1016/0278-4343(88) 90080-5.

Bothner, M. H., C. M. Parmenter, and J. D. Milliman (1981), Temporal and spatial variations in suspended matter in continental shelf and slope waters off the north-eastern United States, Estuarine Coastal Shelf Sci., 13, 213-234, doi:10.1016/S0302-3524(81)80077-1.

Charette, M. A., S. B. Moran, S. M. Pike, and J. N. Smith (2001), Investigating the carbon cycle in the Gulf of Maine using the natural tracer thorium 234, J. Geophys. Res., 106, 11,553-11,579, doi:10.1029/ 1999JC000277.

Cherrier, J., J. E. Bauer, E. R. M. Druffel, R. B. Coffin, and J. P. Chanton (1999), Radiocarbon in marine bacterial: Evidence for the ages of assimilated carbon, Limnol. Oceanogr., 44, 730-736, doi:10.4319/ 1o.1999.44.3.0730.

Collier, R., J. Dymond, S. Honjo, S. J. Manganini, R. Francois, and R. Dunbar (2000), The vertical flux of biogenic and lithogenic material in the Ross Sea: Moored sediment trap observations 1996-1998, Deep Sea Res., Part II, 47, 3491-3520, doi:10.1016/S0967-0645(00)00076-X. Coppola, L., O. Gustafsson, P. Andersson, T. I. Eglinton, M. Uchida, and A. F. Dickens (2007), The importance of ultrafine particles as a control on the distribution of organic carbon in Washington Margin and Cascadia Basin sediments, Chem. Geol., 243, 142-156, doi:10.1016/j.chemgeo.2007.05.020 
Druffel, E. R. M., and P. M. Williams (1990), Identification of a deep marine source of particulate organic carbon using bomb ${ }^{14} \mathrm{C}$, Nature, 347, 172-174, doi:10.1038/347172a0.

Druffel, E. R. M., S. Honjo, S. Griffin, and C. W. Wong (1986), Radiocarbon in particulate matter from the eastern Sub-arctic Pacific Ocean: Evidence of a source of terrestrial carbon to the deep sea, Radiocarbon, 28, 397-407.

Druffel, E. R. M., P. M. Williams, J. E. Bauer, and J. R. Ertel (1992), Cycling of Dissolved and Particulate Organic Matter in the Open Ocean, J. Geophys. Res., 97, 15,639-15,659, doi:10.1029/92JC01511.

Druffel, E. R. M., S. Griffin, J. E. Bauer, D. M. Wolgast, and X.-C. Wang (1998a), Distribution of particulate organic carbon and radiocarbon in the water column from the upper slope to the abyssal NE Pacific Ocean, Deep Sea Res., Part II, 45, 667-687, doi:10.1016/S0967-0645(98) 00002-2.

Druffel, E. R. M., S. Griffin, S. Honjo, and S. J. Manganini (1998b), Evidence of old carbon in the deep water column of the Panama Basin from natural radiocarbon measurements, Geophys. Res. Lett., 25(10), 1733-1736, doi:10.1029/98GL01157.

Duce, R. A., et al. (1991), The atmospheric input of trace species to the world ocean, Global Biogeochem. Cycles, 5, 193-259, doi:10.1029/ 91GB01778.

Dunbar, R. B., A. R. Leventer, and D. A. Mucciarone (1998), Water column sediment fluxes in the Ross Sea, Antarctica: Atmospheric and sea ice forcing, J. Geophys. Res., 103, 30,741-30,759, doi:10.1029/ 1998JC900001.

Dunne, J. P., J. L. Sarmiento, and A. Gnanadesikan (2007), A synthesis of global particle export from the surface ocean and cycling through the ocean interior and on the seafloor, Global Biogeochem. Cycles, 21, GB4006, doi:10.1029/2006GB002907.

Eglinton, T. I., G. Eglinton, L. Dupont, E. R. Sholkovitz, D. Montluçon, and C. M. Reddy (2002), Composition, age, and provenance of organic matter in NW African dust over the Atlantic Ocean, Geochem. Geophys. Geosyst., 3(8), 1050, doi:10.1029/2001GC000269.

François, R., S. Honjo, R. Krishfield, and S. J. Manganini (2002), Factors controlling the flux of organic carbon to the bathypelagic zone of the ocean, Global Biogeochem. Cycles, 16(4), 1087, doi:10.1029/ 2001GB001722.

Freudenthal, T., S. Neuer, H. Meggers, R. Davenport, and G. Wefer (2001) Influence of particle advection and organic matter degradation on sediment accumulation and stable nitrogen isotope ratios along a productivity gradient in the Canary Islands region, Mar. Geol., 177, 93-109, doi:10.1016/S0025-3227(01)00126-8.

Goñi, M. A., M. B. Yunker, R. W. Macdonald, and T. I. Eglinton (2005), The supply and preservation of ancient and modern components of organic carbon in the Canadian Beaufort Shelf of the Arctic Ocean, Mar. Chem., 93, 53-73, doi:10.1016/j.marchem.2004.08.001.

Gustafsson, O., et al. (2009), Brown clouds over south Asia: Biomass or fossil fuel combustion?, Science, 323, 495-498, doi:10.1126/science. 1164857.

Hay, B. J., S. Honjo, S. Kempe, V. A. Ittekot, E. T. Degens, T. Konuk, and E. Izdar (1990), Interannual variability in particle flux in the southwestern Black Sea, Deep Sea Res., Part A, 37, 911-928, doi:10.1016/0198-0149 (90)90103-3.

Hedges, J. I. (1992), Global biogeochemical cycles: Progress and problems, Mar. Chem., 39, 67-93, doi:10.1016/0304-4203(92)90096-S

Honda, M. C., M. Kusakabe, S. Nakabayashi, and M. Katagiri (2000), Radiocarbon of sediment trap samples from the Okinawa trough: Lateral transport of ${ }^{14} \mathrm{C}$-poor sediment from the continental shelf, Mar. Chem., 68, 231-247, doi:10.1016/S0304-4203(99)00080-8.

Honjo, S., D. W. Spencer, and J. W. Farrington (1982), Deep advective transport of lithogenic particles in Panama Basin, Science, 216, 516-518, doi:10.1126/science.216.4545.516.

Honjo, S., J. Dymond, R. Collier, and S. J. Manganini (1995), Export production of particles to the interior of the equatorial Pacific Ocean during the 1992 EqPac experiment, Deep Sea Res., Part II, 42, 831-870, doi:10.1016/0967-0645(95)00034-N.

Honjo, S., J. Dymond, W. Prell, and V. Ittekot (1999), Monsoon-controlled export fluxes to the interior of the Arabian Sea, Deep Sea Res., Part II, 46, 1859-1902, doi:10.1016/S0967-0645(99)00047-8.

Honjo, S., S. J. Manganini, R. A. Krishfield, and R. François (2008), Particulate organic carbon fluxes to the ocean interior and factors controlling the biological pump: A synthesis of global sediment trap programs since 1983, Prog. Oceanogr., 76, 217-285, doi:10.1016/j.pocean.2007.11.003

Honjo, S., R. A. Krishfield, T. I. Eglinton, S. J. Manganini, J. N. Kemp, K. W. Doherty, J. Hwang, T. K. McKee, and T. Takizawa (2010), Biological pump processes in the cryopelagic and hemipelagic Arctic
Ocean: Canada Basin and Chukchi Rise, Prog. Oceanogr., 85, 137-170, doi:10.1016/j.pocean.2010.02.009

Hwang, J., and E. R. M. Druffel (2003), Lipid-like material as the source of the uncharacterized organic carbon in the ocean?, Science, 299, 881-884, doi:10.1126/science. 1078508

Hwang, J., and E. R. M. Druffel (2006), Carbon isotope ratios of organic compound fractions in oceanic suspended particles, Geophys. Res. Lett., 33, L23610, doi:10.1029/2006GL027928.

Hwang, J., E. R. M. Druffel, S. Griffin, K. L. Smith, R. J. Baldwin, and J. E. Bauer (2004), Temporal variability of $\Delta^{14} \mathrm{C}, \delta{ }^{13} \mathrm{C}$, and $\mathrm{C} / \mathrm{N}$ in sinking particulate organic matter at a deep time series station in the northeast Pacific Ocean, Global Biogeochem. Cycles, 18, GB4015, doi:10.1029/ 2004GB002221.

Hwang, J., E. R. M. Druffel, and T. Komada (2005), Transport of organic carbon from the California coast to the slope region: A study of $\Delta^{14} \mathrm{C}$ and $\delta^{13} \mathrm{C}$ signatures of organic compound classes, Global Biogeochem. Cycles, 19, GB2018, doi:10.1029/2004GB002422.

Hwang, J., E. R. M. Druffel, and J. E. Bauer (2006), Incorporation of aged dissolved organic carbon (DOC) by oceanic particulate organic carbon (POC): An experimental approach using natural carbon isotopes, Mar. Chem., 98, 315-322, doi:10.1016/j.marchem.2005.10.008.

Hwang, J., T. I. Eglinton, R. A. Krishfield, S. J. Manganini, and S. Honjo (2008), Lateral organic carbon supply to the deep Canada Basin, Geophys. Res. Lett., 35, L11607, doi:10.1029/2008GL034271.

Hwang, J., S. J. Manganini, D. B. Montluçon, and T. I. Eglinton (2009a), Dynamics of particle export on the Northwest Atlantic margin, Deep Sea Res., Part I, 56, 1792-1803, doi:10.1016/j.dsr.2009.05.007.

Hwang, J., D. Montluçon, and T. I. Eglinton (2009b), Molecular and isotopic constraints on the sources of suspended particulate organic carbon on the northwestern Atlantic margin, Deep Sea Res., Part I, 56, 1284-1297, doi:10.1016/j.dsr.2009.01.012.

Ingalls, A. E., S. R. Shah, R. L. Hansman, L. I. Aluwihare, G. M. Santos, E. R. M. Druffel, and A. Pearson (2006), Quantifying archaeal community autotrophy in the mesopelagic ocean using natural radiocarbon, Proc. Natl. Acad. Sci. U. S. A., 103, 6442-6447, doi:10.1073/pnas.0510157103.

Ingamells, C. O. (1970), Lithium metaborate flux in silicate analysis, Anal. Chim. Acta, 52, 323-334, doi:10.1016/S0003-2670(01)80963-6.

Inthorn, M., T. Wagner, G. Scheeder, and M. Zabel (2006), Lateral transport controls distribution, quality, and burial of organic matter along continental slopes in high-productivity areas, Geology, 34, 205-208, doi:10.1130/ G22153.1.

Jahnke, R. A. (1996), The global ocean flux of particulate organic carbon: Areal distribution and magnitude, Global Biogeochem. Cycles, 10, 71-88, doi:10.1029/95GB03525.

Jones, G. A., and A. R. Gagnon (1994), Radiocarbon chronology of Black Sea sediments, Deep Sea Res., Part I, 41, 531-557, doi:10.1016/09670637(94)90094-9.

Jones, G. A., A. R. Gagnon, K. F. von Reden, A. P. McNichol, and R. J. Schneider (1994), High-precision AMS radiocarbon measurements of central Arctic Ocean sea waters, Nucl. Instrum. Methods B, 92, 426-430, doi:10.1016/0168-583X(94)96048-8.

Kao, S.-J., and K.-K. Liu (1996), Particulate organic carbon export from a subtropical mountainous river (Lanyang Hsi) in Taiwan, Limnol. Oceanogr., 41, 1749-1757, doi:10.4319/lo.1996.41.8.1749.

Karakas, G., N. Nowald, M. Blaas, P. Marchesiello, S. Frickenhaus, and R. Schlitzer (2006), High-resolution modeling of sediment erosion and particle transport across the northwest African shelf, J. Geophys. Res. 111, C06025, doi:10.1029/2005JC003296.

Karner, M. B., E. F. DeLong, and D. M. Karl (2001), Archaeal dominance in the mesopelagic zone of the Pacific Ocean, Nature, 409, 507-510, doi:10.1038/35054051.

Keil, R. G., and G. L. Cowie (1999), Organic matter preservation through the oxygen-deficient zone of the NE Arabian Sea as discerned by organic carbon:mineral surface area ratios, Mar. Geol., 161, 13-22, doi:10.1016/ S0025-3227(99)00052-3

Keil, R. G., D. B. Montlucon, F. G. Prahl, and J. I. Hedges (1994a), Sorptive preservation of labile organic matter in marine sediments, Nature, 370, 549-552, doi:10.1038/370549a0.

Keil, R. G., E. Tsamakis, C. B. Fuh, J. C. Giddings, and J. I. Hedges (1994b), Mineralogical and textural controls on the organic composition of coastal marine sediments: Hydrodynamic separation using SPLITTfraction, Geochim. Cosmochim. Acta, 58, 879-893, doi:10.1016/00167037(94)90512-6

Klaas, C., and D. E. Archer (2002), Association of sinking organic matter with various types of mineral ballast in the deep sea: Implications for the rain ratio, Global Biogeochem. Cycles, 16(4), 1116, doi:10.1029/ $2001 \mathrm{~GB} 001765$. 
Lam, P. J., and J. K. B. Bishop (2008), The continental margin is a key source of iron to the HNLC North Pacific Ocean, Geophys. Res. Lett., 35, L07608, doi:10.1029/2008GL033294

Levin, I., and V. Hessheimer (2000), Radiocarbon-A unique tracer of global carbon cycle dynamics, Radiocarbon, 42, 69-80.

Loh, A. N., J. E. Bauer, and E. R. M. Druffel (2004), Variable ageing and storage of dissolved organic components in the open ocean, Nature, 430 , 877-881, doi:10.1038/nature02780.

Macdonald, R. W., F. A. Mclaughlin, and E. C. Carmack (2002), Fresh water and its sources during the SHEBA drift in the Canada Basin of the Arctic Ocean, Deep Sea Res., Part I, 49, 1769-1785, doi:10.1016 S0967-0637(02)00097-3.

Martin, J. H., G. A. Knauer, D. M. Karl, and W. W. Broenkow (1987), VERTEX: Carbon cycling in the northeast Pacific, Deep-Sea Res., 34 , 267-285, doi:10.1016/0198-0149(87)90086-0.

Masiello, C. A., and E. R. M. Druffel (2001), Carbon isotope geochemistry of the Santa Clara River, Global Biogeochem. Cycles, 15, 407-416, doi:10.1029/2000GB001290.

Masiello, C. A., E. R. M. Druffel, and J. E. Bauer (1998), Physical controls on dissolved inorganic radiocarbon variability in the California Current Deep Sea Res., Part II, 45, 617-642, doi:10.1016/S0967-0645(97) 00096-9.

Mayer, L. M. (1994), Surface area control of organic carbon accumulation in continental shelf sediments, Geochim. Cosmochim. Acta, 58 , 1271-1284, doi:10.1016/0016-7037(94)90381-6.

McCave, I. N. (1983), Particle size spectra, behavior, and origin of nepheloid layers over the Nova Scotian continental rise, J. Geophys. Res., 88 7647-7666, doi:10.1029/JC088iC12p07647.

McCave, I. N., I. R. Hall, A. N. Antia, L. Chou, F. Dehairs, R. S. Lampitt, L. Thomsen, T. C. E. van Weering, and R. Wollast (2001), Distribution, composition and flux of particulate material over the European margin at $47^{\circ}-50^{\circ}$ N, Deep Sea Res., Part II, 48, 3107-3139, doi:10.1016/S09670645(01)00034-0.

Measures, C. I., and S. Vink (2000), On the use of dissolved aluminum in surface waters to estimate dust deposition to the ocean, Global Biogeochem. Cycles, 14, 317-327, doi:10.1029/1999GB001188.

Minakawa, M., and Y. Watanabe (1998), Aluminum in the East China Sea and Okinawa Trough, marginal sea areas of the western north Pacific, J. Oceanogr., 54, 629-640, doi:10.1007/BF02823283.

Mollenhauer, G., J. F. McManus, A. Benthien, P. J. Muller, and T. I. Eglinton (2006), Rapid lateral particle transport in the Argentine Basin Molecular ${ }^{14} \mathrm{C}$ and ${ }^{230} \mathrm{Th}_{\mathrm{xs}}$ evidence, Deep Sea Res., Part I, 53, 1224-1243, doi:10.1016/j.dsr.2006.05.005.

Moran, S. B., and R. M. Moore (1991), The potential source of dissolved aluminum from resuspended sediments to the North Atlantic Deep Water, Geochim. Cosmochim. Acta, 55, 2745-2751, doi:10.1016/0016-7037(91) 90441-7.

Murray, R. W., and M. Leinen (1996), Scavenged excess aluminum and its relationship to bulk titanium in biogenic sediment from the central equatorial Pacific Ocean, Geochim. Cosmochim. Acta, 60, 3869-3878, doi:10.1016/0016-7037(96)00236-0.

Nakatsuka, T., N. Handa, N. Harada, T. Sugimoto, and S. Imaizumi (1997), Origin and decomposition of sinking particulate organic matter in the deep water column inferred from the vertical distribution of its $\delta^{14} \mathrm{~N}$ $\delta^{13} \mathrm{C}$ and $\delta^{14} \mathrm{C}$, Deep Sea Res., Part I, 44, 1957-1979, doi:10.1016/ S0967-0637(97)00051-4.

Nelson, J. R., J. R. Beers, R. W. Eppley, G. A. Jackson, J. J. McCarthy, and A. Soutar (1987), A particle flux study in the Santa Monica-San Pedro Basin off Los Angeles: Particle flux, primary production, and transmissometer survey, Cont. Shelf Res., 7, 307-328, doi:10.1016/0278-4343 (87)90071-9.

Ohkouchi, N., T. I. Eglinton, L. D. Keigwin, and J. M. Hayes (2002), Spatial and temporal offsets between proxy records in a sediment drift, Science, 298, 1224-1227, doi:10.1126/science.1075287.

Otosaka, S., O. Togawa, M. Baba, E. Karasev, Y. Volkov, N. Omata, and S. Noriki (2004), Lithogenic flux in the Japan Sea measured with sediment traps, Mar. Chem., 91, 143-163, doi:10.1016/j.marchem.2004.06.006.

Otosaka, S., T. Tanaka, O. Togawa, H. Amano, E. V. Karasev, M. Minakawa, and S. Noriki (2008), Deep sea circulation of particulate organic carbon in the Japan Sea, J. Oceanogr., 64, 911-923, doi:10.1007/s10872-008-0075-4.

Pearson, A., A. P. McNichol, B. C. Benitez-Nelson, J. M. Hayes, and T. I. Eglinton (2001), Origin of lipid biomarkers in Santa Monica Basin surface sediment: A case study using compound-specific $\Delta^{14} \mathrm{C}$ analysis, Geochim Cosmochim Acta 65, 3123-3137, doi:10.1016/S0016-7037(01)00657-3.

Pilskaln, C. H. (2006), The Gulf of Maine benthic nepheloid layer: Particle characterization, dynamics, and transformations, Eos Trans. $A G U$, 87(36), Ocean Sci. Meet. Suppl., Abstract OS45E-02.

Rau, G. H., D. M. Karl, and R. S. Carney (1986), Does inorganic carbon assimilation cause ${ }^{14} \mathrm{C}$ depletion in deep-sea organisms?, Deep Sea Res., Part A, 33, 349-357, doi:10.1016/0198-0149(86)90096-8.

Rea, D. K., and S. A. Hovan (1995), Grain size distribution and depositional processes of the mineral component of abyssal sediments: Lessons from the North Pacific, Paleoceanography, 10, 251-258, doi:10.1029/ 94PA03355

Santschi, P. H., L. Guo, I. D. Walsh, M. S. Quigley, and M. Baskaran (1999), Boundary exchange and scavenging of radionuclides in continental margin waters of the Middle Atlantic Bight: Implications for organic carbon fluxes, Cont. Shelf Res., 19, 609-636, doi:10.1016/S0278-4343 (98)00103-4.

Sherrell, R. M., M. P. Field, and Y. Gao (1998), Temporal variability of suspended mass and composition in the Northeast Pacific water column: Relationships to sinking flux and lateral advection, Deep Sea Res., Part II, 45, 733-761, doi:10.1016/S0967-0645(97)00100-8.

Smith, K. L., R. S. Kaufmann, R. J. Baldwin, and A. F. Carlucci (2001), Pelagic-benthic coupling in the abyssal eastern North Pacific: An 8-year time-series study of food supply and demand, Limnol. Oceanogr., 46 , 543-556, doi:10.4319/1o.2001.46.3.0543.

Suzuki, T., and S. Tsunogai (1988), Daily variation of aerosols of marine and continental origin in the surface air over a small island, Okushiri, in the Japan Sea, Tellus, Ser. B, 40, 42-49, doi:10.1111/j.16000889.1988.tb00211.x.

Taylor, S. R. (1964), Abundance of chemical elements in the continental crust: A new table, Geochim. Cosmochim. Acta, 28, 1273-1285, doi:10.1016/0016-7037(64)90129-2.

Thomsen, L., and G. Gust (2000), Sediment erosion thresholds and characteristics of resuspended aggregates on the western European continental margin, Deep Sea Res., Part I, 47, 1881-1897, doi:10.1016/S0967-0637 (00)00003-0.

Townsend, D. W., L. M. Mayer, Q. Dortch, and R. W. Spinrad (1992), Vertical structure and biological activity in the bottom nepheloid layer of the Gulf of Maine, Cont. Shelf Res., 12, 367-387, doi:10.1016/0278-4343 (92) $90037-\mathrm{K}$

Tsunogai, S., S. Watanabe, and T. Sato (1999), Is there a "continental shelf pump" for the absorption of atmospheric $\mathrm{CO}_{2}$ ?, Tellus, Ser. B, 51, 701-712, doi:10.1034/j.1600-0889.1999.t01-2-00010.x.

Vogel, J. S., J. R. Southon, and E. E. Nelson (1987), Catalyst and binder effects in the use of filamentous graphite for AMS, Nucl. Instrum. Methods Phys. Res., Sect. B, 29, 50-56, doi:10.1016/0168-583X(87)90202-3.

Volk, T., and M. I. Hoffert (1985), Ocean carbon pumps: Analysis of relative strengths and efficiencies in ocean-driven atmospheric $\mathrm{CO}_{2}$ changes, in The Carbon Cycle and Atmospheric $\mathrm{CO}_{2}$ : Natural Variations Archaen to Present, Geophys. Monogr. Ser., vol. 32, edited by E. T. Sundquist and W. S. Broecker, pp. 99-110, AGU, Washington, D. C.

Wakeham, S. G. (2006), Radiocarbon compositions of biomarkers in sediment traps and surface sediments in the ocean, Eos, Trans. $A G U$ 87(36), Ocean Sciences Meeting Suppl., Abstract OS16K-05

Wang, X.-C., E. Druffel, and C. Lee (1996), Radiocarbon in organic compound classes in particular organic matter and sediment in the deep northeast Pacific Ocean, Geophys. Res. Lett., 23, 3583-3586, doi:10.1029/ 96GL03423.

Wang, X.-C., E. R. M. Druffel, S. Griffin, C. Lee, and M. Kashgarian (1998), Radiocarbon studies of organic compound classes in plankton and sediment of the northeastern Pacific Ocean, Geochim. Cosmochim. Acta, 62, 1365-1378, doi:10.1016/S0016-7037(98)00074-X.

Wuchter, C., S. Schouten, H. T. S. Boschker, and J. S. Sinninghe Damste (2003), Bicarbonate uptake by marine Crenarchaeota, FEMS Microbiol. Lett., 219, 203-207, doi:10.1016/S0378-1097(03)00060-0.

E. R. M. Druffel, Department of Earth System Science, University of California, Irvine, 3222 Croul Hall, Irvine, CA 92697, USA.

T. I. Eglinton, Woods Hole Oceanographic Institution, Woods Hole Road, Woods Hole, MA 02543, USA.

J. Hwang, POSTECH Ocean Science and Technology Institute, Pohang University of Science and Technology, Pohang, 790-784, South Korea (jhwang@postech.ac.kr) 